\title{
Guselkumab (Tremfya)
}

\author{
MUDr. Jan Hugo, doc. MUDr. Spyridon Gkalpakiotis, Ph.D., MBA \\ Dermatovenerologická klinika 3. LF UK a FNKV, Praha
}

S prohloubením poznání patogeneze psoriázy byl rozpoznán zásadní význam interleukinu 23 (IL-23), což reflektoval i vývoj nových léčebných prípravků. Guselkumab je prvním schváleným biologikem se specifickou inhibicí IL-23. Náš článek shrnuje údaje o léčebném potenciálu tohoto léku a rekapituluje nejnovější informace o působení samotného interleukinu 23.

Klíčová slova: psoriáza, biologická terapie, interleukin 23, guselkumab.

\section{Guselkumab (Tremfya)}

As knowledge of the pathogenesis of psoriasis deepened, the crucial importance of interleukin 23 (IL-23) was recognized. This was also reflected by the development of new therapies. Guselkumab is the first approved biologic drug with specific inhibition of IL-23. Our article summarizes the therapeutic potential of this drug and recapitulates the latest information on the effect of interleukin 23.

Key words: psoriasis, biologic therapy, interleukin 23, guselkumab.

\section{Úvod}

Psoriáza je autoinflamatorní systémové onemocnění, s chronickým průběhem, vznikající u geneticky predisponovaných jedinců. Prevalence se $v$ rámci středoevropské populace udává v rozmezí 2-4%, o něco vyšší je v severských zemích Evropy.

Kromě typického postižení kưže, a často též kloubního systému, může být patologický zánět prítomný v mnoha dalších orgánech, pacienti s psoriázou mají proto zvýšené riziko rozvoje řady komorbidit, včetně onemocnění ze skupiny IMID (Immune-mediated inflammatory disease) (1)

Podstata rozvoje choroby je multifaktoriální, ke klinické manifestaci dochází u predisponovaných jedinců po vystavení provokačním vlivům zevního prostředí (např. trauma, infekce, změna medikace, stres aj.) (2).

$\checkmark$ posledních letech došlo u psoriázy k velkým pokrokům, a to nejen v možnostech terapie, ale i v pochopení samotné etiopatogeneze. Dlouhou dobu se vědecké bádání soustředilo zejména na Th1 subpopulaci T-lymfocytů a cytokin tumor nekrotizující faktor alfa (TNF-alfa). Zásadní posun nastal díky objevení lL-23 v roce 2000. Zvýšená exprese receptoru pro IL-23 byla detekována na epidermálních i dermálních CD3+ lymfocytech a dendritických buňkách (DC - dendritic cell) u pacientů s psoriázou (3).

Krátce po objevu IL-23 bylo zjištěno, že ovlivňuje diferenciaci do té doby neznámé subpopulace T-lymfocytů, prítomné v psoriatických ložiscích. Tato subpopulace se svým cytokinovým profilem zcela odlišovala od Th1 a Th2 subpopulací. Hlavním efektorovým interleukinem se ukázal být interleukin 17 (IL-17), a proto byla i celá subpopulace následně označena jako Th17 (4).

Dnes je již známo, že nepatogenní Th17 lymfocyty - vyskytující se zcela přirozeně v celém organismu - mají klíčovou roli v protekci bariérových epitelů pred specifickými patogeny. Udržují fyziologickou hladinu IL-17, která je nezbytná pro zachování kožní a slizniční ochrany před kandidami a extracelulárními bakteriemi, $\checkmark$ prípadě potřeby dokáže tento cytokin velice rychle navodit účinný obranný zánět. IL-17 ale vykazuje prozánětlivé působení nejenom u této protektivní funkce. Má napríklad schopnost aktivovat keratinocyty, které $v$ důsledku aktivace vykazují poruchy maturace, jejich proliferace je urychlená, jsou zvýšeně rezistentní k apoptóze a produkují cytokiny s parakrinním efektem (5).

Oproti tomu patogenní Th17 lymfocyty vznikající až v důsledku různých patologických stimulů - produkujíl lL-17 v nadměrném nefyziologickém množství, čímž dochází i k neúměrné aktivaci keratinocytů, a tím i rozvoji typických znaků psoriázy. Patogenní Th17 lymfocyty navíc produkují řadu dalších prozánětlivých cytokinů (6), zejména interleukin 22 (IL-22), a v menší míře i TNF-alfa, které přispívají k vysoké aktivitě psoriázy.

Zmíněné patologické stimuly vedou k sekreci ll-23 aktivovanými dendritickými buňkami, kdy secernovaný IL-23 stimuluje diferenciaci naivních Th lymfocytů právě na patogenní Th17 lymfocyty. IL-23 tak Ize chápat jako nadřazený regulační faktor patogenních Th17 lymfocytů (obr. 1).

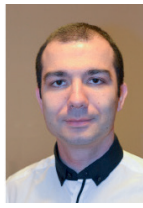




\section{FARMAKOLOGICKÝ PROFIL}

\section{GUSELKUMAB (TREMFYA)}

Jedním z nejnovějších poznatků je i zjištění, že IL-23 kromě patogenních Th17 lymfocytů rovněž podporuje vznik tkáňových pamětových buněk (TRM cells - Tissue Resident Memory cells), které jsou zodpovědné za rekurenci zánětlivého vzplanutí v již zhojených ložiscích (7).

Blokáda IL-23 tedy komplexně eliminuje mechanismy vedoucí jak k udržování aktivní fáze, tak i rekurence onemocnění.

\section{Charakteristika přípravku}

Guselkumab (obchodní název Tremfya) je plně humánní monoklonální protilátka, predstavovaná imunoglobulinem G1 lambda (lgG1 $\lambda$ ), vázající se s vysokou specificitou i afinitou na proteinovou podjednotku p19 interleukinu 23. Tvorba probíhá pomocí rekombinantní DNA technologie v ovariálních buňkách křečka čínského.

Svojí vazbou znemožňuje navázání IL-23 na odpovídající receptorový komplex IL-23R a brání tak rozvoji jeho patologického prozánětlivého působení, které již bylo výše popsáno. Protože se jedná o selektivní blokádu IL-23, není ovlivněna diferenciace nepatogenních Th17 lymfocytů, a tím je zachována fyziologická homeostáza na slizničních površích.

\section{Indikace a dávkování}

Terapie guselkumabem je indikována u pacientů se středně těžkou až těžkou ložiskovou psoriázou, kteří jsou kandidáti na systémovou léčbu. Aplikace guselkumabu se provádí subkutánně, pomocí předplněné injekční stř́kačky či nově dostupného předplněného pera.

Doporučená dávka je vždy 100 mg, podávaná v týdnu 0, 4 a následně každých 8 týdnů. U pacientů, kteři po 16 týdnech nevykazujížádné terapeutické zlepšení, je nutné zvážit ukončení terapie.

Dosažení maximální plazmatické koncentrace je přibližně za 5,5 dne, s 49\% biologickou dostupností, po jedné 100mg s.c. dávce. Střední hodnota poločasu eliminace je zhruba 15-18 dní. U pacientů s nadváhou, ani u starších pacientů ( $\geq 65$ let) není nutná úprava dávky.

\section{Výsledky klinických studií}

Hodnocení účinnosti, bezpečnosti a snášenlivosti léčby proběhlo na základě čtyř multicentrických klinických studií VOYAGE 1 a 2, NAVIGATE a ECLIPSE. Jednalo se o randomizované, dvojitě zaslepené studie, kontrolované placebem a/ nebo aktivním komparátorem (adalimumab

Obr. 1. Patologická prozánětlivá kaskáda IL-17/23

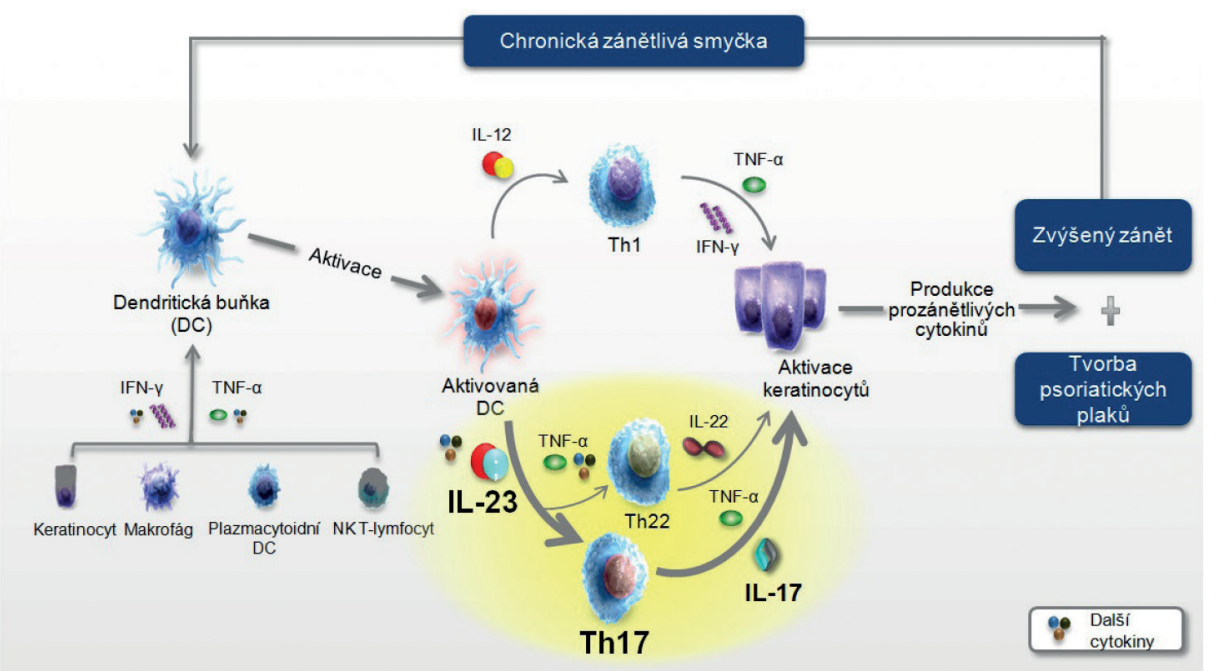

Adaptováno: Nestie, et al. N Engl J Med 2009; 361: 496-509; Lynde, et al. J Am Acad Dermatol 2014; 71: 141-150; Fujita. J Dermatol Sci 2013; 72: 3-8

ve studiích VOYAGE, ustekinumab ve studii NAVIGATE a secukinumab ve studii ECLIPSE). Celkem bylo do těchto studií zařazeno více jak 3500 dospělých pacientů.

Hlavními kritérii účinnosti byly hodnoty PASI skóre a IGA skóre. PASI skóre (Psoriasis Area and Severity Index) je index, který umožňuje objektivizovat tízi psoriázy, se vztažením k rozsahu postižené kožní plochy. Hodnotí se erytém ložisek, tloušt'ka ložisek a deskvamace ložisek. PASI využívá bodového hodnocení od 0 do 72, se vzrůstající závažností prímo vzrůstá i počet bodů. V klinických studiích je většinou zjištováno tzv. PASI 75/90/100, což je zlepšení o 75 \% (respektive 90 \% či 100 \%) oproti počátečnímu stavu. IGA skóre (Investigator Global Assessment) je index, kterým hodnotící lékař stanovuje na škále od 1 do 4 celkovou závažnost kožního onemocnění ( 0 - bez kožních projevư, 1 - minimální postižení, 2 - mírné postižení, 3 - středně těžké postižení, 4 - těžké postižení).

První podstatné výsledky vzešly ze studie VOYAGE 1, ve které bylo celkově randomizováno 837 pacientů. Ve skupině od začátku léčené guselkumabem dosáhlo v 16. týdnu 73,3% pacientů PASI 90 a 85,1 \% pacientů IGA 0/1, což byl signifikantně lepší výsledek v porovnání jak s placebem (2,9\% u PASI 90 a 6,1 \% u IGA 0/1), tak adalimumabem (49,7 \% u PASI 90 a 65,9\% u IGA 0/1). Výrazně lepší klinická odpověd'oproti placebu i adalimumabu byla zaznamenána i ve 24. a 48. týdnu. Pacienti, kteří byli nejprve léčeni placebem, s následným převedením na guselkumab v 16. týdnu, dosáhli podobného zlepšení jako pacienti, kteří byli zařazeni do skupiny s guselkumabem od samého začátku (8).
Studie NAVIGATE se účastnilo 871 pacientů, u kterých bylo zahájeno podávání ustekinumabu ve standardním schématu. U 268 pacientů bylo po 16 týdnech IGA skóre $\geq 2$. V této skupině byla provedena randomizace, 133 pacientů pokračovalo v aplikování ustekinumabu, u 135 pacientů byla provedena změna terapie na guselkumab. V 52. týdnu studie byly hodnoceny výsledky, kdy ve všech sledovaných parametrech dosáhl guselkumab signifikantně lepších výsledků. Ve skupině léčených guselkumabem byl relativní pokles PASI 6,7 (vs. 2,5 pro ustekinumab), u 51,1\% pacientů bylo dosaženo PASI 90 (vs. 24,1 \% pro ustekinumabu), u 20 \% bylo dosaženo kompletního zhojení PASI 100 (vs. 7,5\% pro ustekinumab) (9).

Ve studii ECLIPSE došlo k př́mému porovnání guselkumabu a secukinumabu, jednalo se tedy o tzv. head-to-head studii. Soubor pacientů byl zcela srovnatelný, guselkumab dostávalo 534 pacientů, secukinumab dostávalo 514 pacientů. Primární cíl studie bylo stanovit procento pacientů, kteři ve 48. týdnu dosáhnou zlepšení PASI 90. Ve skupině léčených guselkumabem dosáhlo tohoto zlepšení 84,5\% pacientů, ve skupině léčených secukinumabem $70 \%$ pacientů. Výsledek byl statisticky signifikantní (10).

\section{Bezpečnost terapie}

Bezpečnost guselkumabu byla sledována ve všech třech fázích klinického testování. V klinických studiích byl guselkumab dobře tolerován a profil nežádoucích účinků (Nú) byl podobný jako u placeba. Celkově bylo ve studiích guselkumabu exponováno přes 3000 pacientů, u cca 1900 
INZERCE 
z nich po dobu nejméně 6 měsíců, u cca 1200 pacientů po dobu nejméně jednoho roku.

Nejčastějšími hlášenými Nú byly nezávažné respirační infekce (četnost nad $10 \%$ ), incidence těchto Nú však byla stejná jako u pacientů, jimž byly podávány komparátory (adalimumab či ustekinumab). Méně často (četnost 1-10 \%) se vyskytovaly bolesti hlavy, artralgie a pruritus. Nebylo zaznamenáno riziko vážných Nú, včetně malignit či závažných kardiovaskulárních přihod (MACE - major adverse cardiac events). Rovněž nebyly zjištěny žádné nové bezpečnostní signály

\section{LITERATURA}

1. Vanaclocha F, et al. Immune-mediated inflammatory diseases and other comorbidities in patients with psoriasis: baseline characteristics of patients in the AQUILES study. Actas Dermosifiliogr. 2015 Jan-Feb; 106(1): 35-43.

2. Koo S, et al. Infectious complications associated with immunomodulating biologic agents. Infect Dis ClinNorth Am 2010; 24: 285.

3. Tonel G, et al. Cutting edge: A critical functional role for IL23 in psoriasis. J Immunol. 2010 Nov 15; 185(10): 5688-5691. 4. Aggarwal S, et al. Interleukin-23 promotes a distinct CD4 $T$ cell activation state characterized by the production of interleukin-17. J Biol Chem. 2003; 78: 1910-1914.

5. Lønnberg AS, et al. Targeting of interleukin-17 in the treatment of psoriasis. Clin Cosmet Investig Dermatol 2014; 7: 251-259. u pacientů, kteří přešli z léčby adalimumabem nebo ustekinumabem na léčbu guselkumabem (11).

\section{Závěr}

Guselkumab je prvním schváleným biologikem v terapii ložiskové psoriázy se specifickou inhibicí ll-23.

V uváděných klinických studiích prokázal dlouhodobou vysokou účinnost při ověřeném bezpečnostním profilu.

Nově publikovaná data z 4letého sledování v rámci studie VOYAGE 1 ukázala, že u 82 \% pacientů, kteří dosáhli po 16 týdnech zlepšení o 90 \% oproti počátečnímu stavu (PASI 90), toto zlepšení přetrvává i po 204 týdnech terapie (12).

Kromě efektu na typické psoriatické plaky byla ve studii VOYAGE demonstrována účinnost i na postižení v kapiliciu a na nehtech, lokalitách známých svou rezistencí na konvenční druhy léčby (13).

Kromě klinických výsledků poskytuje guselkumab pacientům výhodu také v nižší frekvenci aplikací (1× za 8 týdnů) a možnosti výběru mezi injekční stříkačkou a perem.
6. Gaffen SL, et al. The IL-23-IL-17 immune axis: from mechanisms to therapeutic testing. Nat Rev Immunol. 2014 Sep; 14(9): 585-600

7. Cheuk S, et al. Epidermal Th22 and Tc17 Cells Form a Localized Disease Memory in Clinically Healed Psoriasis; J Immunol 2014; 192: 3111-3120.

8. Megna $M$, et al. Guselkumab for the treatment of psoriasis; Exp Opin Biol Ther 2018; 18(4): 459-468.

9. Langley RG, et al. Efficacy and safety of guselkumab in patients with psoriasis who have an inadequate response to ustekinumab: results of the randomized, double-blind, phase III NAVIGATE trial. Br J Dermatol. 2018 Jan; 178(1): 114-123.

10. Reich K, et al. Guselkumab versus secukinumab for the treatment of moderate-to-severe psoriasis (ECLIPSE): results from a phase 3, randomised controlled trial. Lancet. 2019 Sep 7; 394(10201): 831-839.

11. Souhrn údajů o prípravku Tremfya 100 mg, datum revize textu: 26.11. 2018.

12. Griffiths CEM, et al. Maintenance of response with up to 4 years of continuous guselkumab treatment: Results from the VOYAGE 1 phase 3 trial. Presented at: 2019 Fall Clinical Dermatology Conference; October 17-20, 2019 Las Vegas, NV.

13. Foley P, et al. Efficacy of Guselkumab Compared With Adalimumab and Placebo for Psoriasis in Specific Body Regions: A Secondary Analysis of 2 Randomized Clinical Trials. JAMA Dermatol. 2018 Jun 1; 154(6): 676-683.

\section{SOLEN MEDICAL EDUCATION}

\section{predplatné časopisu}

\section{Dermatologie pro praxi}

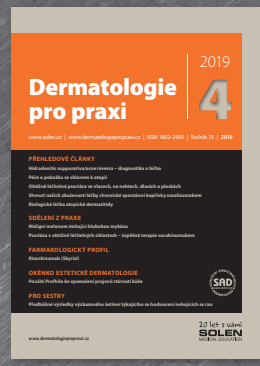

$0 \leqslant 35$

MLADÍ LÉKAŘI
$50 \%$ SLEVA
260 Kč

Fandíme mladým lékařùm, a proto předplatitelé do 35 let získají $50 \%$ slevu.

Stačí jen při objednávce do poznámky uvést rok narození.

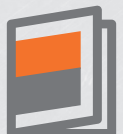

TIŠTĚNÝ ČASOPIS

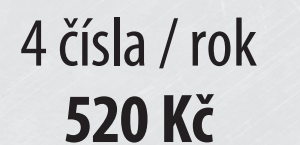

Přistup k aktuálnímu číslu na www.dermatologiepropraxi.cz Supplementa a odborné publikace Aktuální informace o pripravovaných kongresech

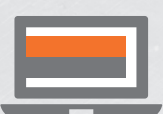

ELEKTRONICKÁ VERZE

4 čisla / rok 390 Ǩ́

Elektronická verze se slevou $25 \%$ k zakoupení na www.alza.cz/media Čtěte nás na počítači nebo na mobilních zařizeních

\section{OBJEDNÁVEJTE}

